\title{
Summary of Questionnaire Results-1980 Weathercasters Conference, Denver, Colo.
}

The 10th Conference on Radio and Television Weathercasting was held 14-15 June 1980 in Denver, Colo. At that time, the AMS Board of Radio and Television Weathercasting asked those broadcasters attending to complete a questionnaire, responding anonymously to questions about market size served, staff size, equipment available for the preparation of weathercasts, union status, and other items of comparative interest.

This particular survey was aimed at television weathercasters only. There were 81 respondents, of which 51 (63\%) were current holders of the AMS Seal of Approval for Television. Answers to the questions were divided by market size into two groups, split at market size 50; and in addition, comparisons were made between AMS Sealholders and non-Sealholders. Here are the results from markets 1-50:

1) Total responses: $42 \quad$ Sealholders: 31

Non-Sealholders: 11

2) Union members: $53 \% \quad$ Non-union: $47 \%$

3) Number of years at current television station by market size:

Market Size:

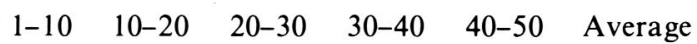

No. of years:

$\begin{array}{llllll}11.7 & 4.0 & 2.6 & 4.4 & 6.3 & 3.2\end{array}$

4) Responses to the question asking what equipment and data sources were available for weathercast preparation:
$100 \%$ of radars are colorized
95\% have State Weather Wire
91\% have NAFAX facsimile
$76 \%$ have a GOES-tap or access
$67 \%$ have their own radar
$50 \%$ have Service A teletypewriter
$31 \%$ have radar facsimile
$29 \%$ have outside computer service
$21 \%$ have Service 604 teletypewriter
$19 \%$ have Service C teletypewriter

In addition, $17 \%$ listed other equipment-most specifying that they had their own computer in-house.

5) When asked what their opinion was regarding the degree of cooperation with the local National Weather Service Office:

$$
\begin{aligned}
& 56 \% \text { said excellent; } 34 \% \text { good; } 5 \% \text { fair; } \\
& \text { and } 5 \% \text { poor cooperation. }
\end{aligned}
$$

6) When asked how much money they could reasonably expect their station to spend to interface with AFOS or with computer graphics, responses by market size were

\begin{tabular}{|c|c|c|c|c|c|}
\hline \multicolumn{6}{|c|}{ Market Size: } \\
\hline $1-10$ & $10-20$ & $20-30$ & $30-40$ & $40-50$ & Average \\
\hline \multicolumn{6}{|c|}{ Amount (\$): } \\
\hline 3050 & 22500 & 20000 & 23600 & 25000 & 24000 \\
\hline
\end{tabular}
as follows:
The results that seem to stand out are the depth of the equipment list at most stations, and the rapid emplacement of GOES service and live, colorized radar as essentials for the TV meteorologist.

One unusual result is that, of the 31 Sealholders, only $58 \%$ displayed the Seal in any form. Many respondents to this question said "not permitted by management."

The results from responses listing market sizes 50-100+ follow:

1) Total responses: 39 Sealholders: 20

Non-Sealholders: 19

2) Union members: $13 \%$ Non-union: $82 \%$

(Two not responding).

3) Number of years at current television station by market size:

Market Size:

50-60 60-70 70-80 80-90 90-100>100 Average No. of years:

$\begin{array}{lllllll}5.0 & 4.7 & 6.3 & 14.5 & 6.9 & 2.0 & 6.6\end{array}$

4) Responses to the question asking what equipment and data sources were available for weathercast preparation:

$82 \%$ have NAFAX facsimile

$77 \%$ have State Weather Wire

$67 \%$ have Service A teletypewriter

$64 \%$ have their own radar

$38 \%$ have radar facsimile

$15 \%$ have GOES-tap or access

$10 \%$ have Service C teletypewriter

$10 \%$ have a computer service

$8 \%$ have Service 604 teletypewriter

$5 \%$ have their own computer

Seventy-seven percent of the owned radars and radar facsimile hookups were colorized.

5) When asked what their opinion was regarding the degree of cooperation with the local National Weather Service Office:

$64 \%$ said excellent; $\quad 23 \%$ said good; $\quad 8 \%$ said fair (Two not responding).

6) When asked how much money they could reasonably expect their stations to spend to interface with AFOS 
and/or computer graphics, responses by market size were as follows:

\section{Market Size:}

50-60 60-70 70-80 80-90 90-100>100 Average

Amount (\$):

$\begin{array}{lllllll}17000 & 17700 & 8300 & 7500 & 20000 & 10400 & 13500\end{array}$

Of the Sealholders in this group of markets, $80 \%$ displayed the Seal.

Perhaps of greatest interest were the thoughtful answers to this last question: "The ' 80 s will be changing times for our profession. What are the most important future problems for this group to consider?' Responses can be grouped into main areas of concern, which are listed here in order based on the number of times they were mentioned:

1) Concern over weather data availability in the age of AFOS was easily the most of ten mentioned. The conversion from facsimile and teletypewriter to AFOS interconnects, the expense of such conversion, keeping up with this new technology, and the effect the conversion will have on weathercasting were all mentioned frequently.

2) The second most often listed concern (in terms of total mentions) involved professional ethics. Several respondents suggested that a code of ethics and standards was needed for radio and TV weathercasters specifically. Suggestions were made that display of the AMS Seal be mandatory and that meteorologists be licensed by the AMS or by the state or federal government. There was even a proposal that an agency be formed jointly with NWS to monitor "those whose lack of professionalism constitutes a public hazard and a disgrace." Many noted an increase in the number of broadcasters calling themselves meteorologists-but without formal training or degree.

3) Listed third in total responses was a keen interest in computer graphics and animation. There is a general consensus that the ' 80 s will see a rapid conversion to electronic weather-and that the cost and type of such conversion, as well as its effect upon the public presentation of weather, should be observed closely.

4) Mentioned fourth was a desire to see better communication of weather data to the public-using new data sources well as an integral, understandable part of a weathercast. Many said better data sources should prompt revised procedures for severe weather dissemination and cooperation with the National Weather Service.

5) The changing role of broadcasters as new television technologies fragment the airwaves, and the audience, in the ' $80 \mathrm{~s}$ was listed frequently as a concern. The advent of weathercasting on cable television, national satellite transmissions, PBS, NOAA weather radio, superstations, the Cable News Network, and other sources should be studied.

6) A number of weathercasters felt that joint meetings or projects with news directors and station management would help them understand the importance of professional weathercasts. Suggestions were made that a national poll of public attitudes toward meteorology and weathercasters be undertaken.

7) A perceived disintegration of National Weather Service service and technological adaptation was mentioned by a number of weathercasters. Many weathercasters felt that static or decreasing Weather Service manpower and a perceived gap between technologies becoming available to broadcasters versus systems available to the Weather Service imply a reevaluation of the roles of government versus broadcast and private meteorologists in the dissemination of both general forecasts and severe weather information.

8) Several suggestions were received to establish a nationwide uniform color code scale for colorized radar use.

9) Finally, there were several requests for a communications forum that could be used by broadcast weathercasters-a newsletter, or space in the BULLETIN.

As Program Chairman for the 1981 Weathercasters Conference, to be held in Boston in June 1981, I would like to invite weathercasters and others who might have insight into these questions and problems to submit ideas for discussion at that conference. It is clear from the survey that changing times will require major efforts from broadcast weathercasters to meet the challenges that are evidently on the way.Terry Kelly, AMS Board of Radio and TV Weathercasting 